\title{
Comparative evaluation of glipizide and fenugreek (Trigonella foenum- graecum) seeds as monotherapy and combination therapy on glycaemic control and lipid profile in patients with type 2 diabetes mellitus
}

\author{
Amandeep Singh ${ }^{1}$, Jaswant Rai ${ }^{2}$, Devinder Singh Mahajan ${ }^{3}$
}

${ }^{1}$ Department of Pharmacology, Shri Guru Ram Rai Institute of Medical and Health Sciences, Patel Nagar, Dehradun, Uttarakhand, 248001, India ${ }^{2}$ Department of Pharmacology, ${ }^{3}$ Department of Medicine, Government Medical College and Hospital, Amritsar, Punjab, 143001, India

Received: 19 March 2016 Accepted: 27 April 2016

*Correspondence to: Dr. Amandeep Singh, Email: angad.aman@gmail.com

Copyright: (c) the author(s), publisher and licensee Medip Academy. This is an openaccess article distributed under the terms of the Creative Commons Attribution NonCommercial License, which permits unrestricted noncommercial use, distribution, and reproduction in any medium, provided the original work is properly cited.

\begin{abstract}
Background: Diabetes is commonly associated with dyslipidemia, which is one of the major risk factors of coronary heart disease (CHD), the leading cause of mortality in patients with type 2 diabetic. It is thus desirable that an anti-diabetic drug must provide good glycaemic control and in addition cause correction of dyslipidaemia, at the same time being safe. Fenugreek, a traditional drug has been found to have beneficial effect on glycaemic control as well as lipid profile and may be thus useful in such patients. The study was thus planned to further explore the effect of fenugreek seed on glycaemic control and lipid profile by comparing it with a standard anti-diabetic drug glipizide.
\end{abstract}

Methods: This 12 week, prospective, randomized, open-label, parallel group comparative study was conducted on 60 patients with type 2 diabetes. The patients were randomized to receive either glipizide $5 \mathrm{mg}$ once daily (group A, $\mathrm{n}=20$ ), fenugreek seed extract $500 \mathrm{mg}$ twice a day (group $\mathrm{B}, \mathrm{n}=20$ ), or a combination of glipizide $2.5 \mathrm{mg}$ and fenugreek seed extract $500 \mathrm{mg}$ once daily (group $\mathrm{C}, \mathrm{n}=20$ ). The primary endpoint were the change in fasting blood glucose (FBG), glycated haemoglobin (HbA1c), and lipid profile from baseline after 12 weeks of treatment.

Results: A statistically significant decline in mean FBG levels (group A $-33.97 \%, \mathrm{p}<0.001$; versus group B $-24.62 \%, \mathrm{p}<0.001$; versus group C $-29.96 \%, \mathrm{p}<0.001$ ), and in HbA1c levels (group A $-12.98 \%, \mathrm{p}<0.0001$; group B $-9.38 \%, \mathrm{p}<0.0001$; and group $\mathrm{C}-10.62 \%, \mathrm{p}<0.0001)$ was seen in all three treatment groups. Total cholesterol (TC) reduced non-significantly in group A ($0.98 \%, \mathrm{p}=0.1982)$, whereas in group $\mathrm{B}(-5.66 \%, \mathrm{p}<0.001)$ and group $\mathrm{C}(-3.87 \%$, $\mathrm{p}<0.001)$ it decreased significantly. Non-significant reduction in plasma triglycerides (TG) were seen in group A $(-0.74 \%, \mathrm{p}=0.0669)$, and significant reductions were seen in both group B $(-17.23 \%, \mathrm{p}<0.001)$ and group $\mathrm{C}(-$ $11.34 \%, \mathrm{p}<0.001)$. Low density lipoproteins cholesterol (LDL-C) showed nonsignificant reductions in group A $(-0.74 \%, \mathrm{p}=0.5482)$, and significant reductions in both group $\mathrm{B}(-4.15 \%, \mathrm{p}<0.001)$ and group $\mathrm{C}(-2.68 \%, \mathrm{p}=0.0463)$. Highdensity lipoproteins cholesterol (HDL-C) showed non-significant changes in all three groups (group A $-0.60 \%, p=0.1529$; group B $0.65 \%, p=0.2072$; and group $\mathrm{C} 0.76 \%, \mathrm{p}=0.0543)$. The adverse drug reactions seen were mild in nature and none of the patients was withdrawn from the study because of serious adverse drug reactions.

Conclusions: Monotherapy with fenugreek produced significant improvement in glycaemic control and dyslipidaemia. Glipizide monotherapy was more efficacious in controlling FBG and HbA1c levels than fenugreek monotherapy or in combination with fenugreek; glipizide monotherapy had no effect on lipid profile whereas fenugreek monotherapy was more efficacious in controlling dyslipidaemia than in combination with glipizide. Both drugs as monotherapy or in combination were well-tolerated by the patients.

Keywords: Glipizide, Fenugreek, Type 2 diabetes mellitus, Lipid profile, Glycaemic control 


\section{INTRODUCTION}

Diabetes mellitus is a chronic disease, affecting nearly Diabetes is a major health problem due to its high prevalence, chronic nature and high risk of chronic complications. It is commonly associated with dyslipidemia, which is one of the major risk factors of coronary heart disease (CHD) in diabetic patients. ${ }^{1,2}$ Diabetic dyslipidemia is characterized by hypertriglyceridemia, low high-density lipoproteins, accumulation of cholesterol-rich remnant particles and small dense low density lipoproteins. ${ }^{3,4}$ Numerous prospective cohort studies have indicated that type 2 diabetes mellitus (T2DM) is associated with a two to fourfold increase in risk for $\mathrm{CHD}^{5-8}$ Also, the casefatality rates for myocardial infarction are raised, thus emphasizing the need for primary intervention in patients with diabetes. ${ }^{9-11}$ Overall, CHD is the leading cause of death in individuals with diabetes who are over the age of 35 years, and is responsible for $80 \%$ of mortality in adults with diabetes. ${ }^{12}$ Based on this, adult treatment panel III (ATP III) has advocated that for primary prevention, diabetes should be regarded as a CHD risk equivalent. ${ }^{13,14}$

Although a number of clinical studies have demonstrated the beneficial effects of lipid-lowering agents, literature search showed no published clinical trials that have assessed the protective effect of lipid-lowering agents on CHD exclusively in patients with diabetes. However, analysis of subgroups of patients in several large clinical trials has shown that reducing the levels of low density lipoproteins cholesterol (LDL-C) and plasma triglycerides (TG) and/or raising levels of high-density lipoproteins cholesterol (HDL-C) is associated with reduced rates of $\mathrm{CHD}$ events in patients with diabetes. Trials involving patients with diabetes and coronary artery disease have shown that cholesterol lowering (with statins) substantially reduces the risk of subsequent cardiovascular events. ${ }^{15-19}$ American diabetes association (ADA) guidelines for treatment goals include fasting blood glucose (FBG) 90-130 mg/dl; glycosylated hemoglobin (HbA1c)<7\%; LDL-C <100 mg/dl; TGs <150 $\mathrm{mg} / \mathrm{dl}$; and HDL-C>40 mg/dl. ${ }^{20}$ The Indian council of medical research (ICMR) guidelines for lipid control in diabetes patients recommend total cholesterol (TC) target of $<180 \mathrm{mg} / \mathrm{dl}^{21}$

Currently available therapeutic options for T2DM such as sulfonylurea, metformin, alpha-glucosidase inhibitors, dipeptidyl peptidase-4 inhibitors, meglitinides, thiazolidinedione's, etc. have little or no effect on lipidprofile, have various adverse effects and are far from satisfactory as far as long-term complications are concerned. Therefore search for agents that are effective, have less adverse effects on long-term use and prevent or control the complications are highly desirable.

Various experimental and clinical studies have reported the beneficial effects of fenugreek (Trigonella foenumgraecum) seeds, a traditional Indian medicine on glycaemic control and lipid profile in patients of T2DM. ${ }^{22-36}$ Fenugreek has also been reported to have few mild adverse effects (abdominal distension, diarrhoea and dizziness). ${ }^{22}$ The seeds of fenugreek have the most potent medicinal effects of the plant. ${ }^{37}$ It is mainly the defatted fraction, which has hypoglycaemic effects and lipid lowering actions, especially on elevated cholesterol and TG levels in the blood. ${ }^{38}$ All these factors, i.e. beneficial effect on both blood glucose levels and lipid profile, safety, easy availability and the low cost of fenugreek make it an attractive alternative to be investigated further as an anti-diabetic agent, especially in the Indian context. Though much work on the clinical efficacy of fenugreek in diabetes mellitus has been done, no study comparing it with a standard anti-diabetic drug has been undertaken so far.

Thus, we planned this study to further explore the antidiabetic effect and effect on lipid profile of fenugreek seed extract in Indian population and to compare its effects with glipizide, a known anti-diabetic drug while observing the side effects of both agents.

\section{METHODS}

\section{Study design}

This 12 week, prospective, randomized, open-label, standard-controlled, and parallel group comparative study was conducted in patients with T2DM visiting the outpatient department of medicine of Guru Nanak Dev Hospital, a multispecialty tertiary care hospital attached to government medical college, Amritsar, Punjab, India during the period from May 2004 to November 2005. The study was done in association of Department of Medicine and department of pharmacology of government medical college, Amritsar, Punjab, India.

\section{Study population}

A total of 60 patients with mild to moderate T2DM were enrolled in the study. Patients of both sexes in the age group of 30 to 70 years were included in the study. Patients with the following conditions were excluded from the study: hypersensitivity to fenugreek or glipizide; patients already taking hypolipidaemic drugs; patients already taking anti-diabetic drugs other than these two agents; history of diabetic ketoacidosis; patients in congestive heart failure or advanced coronary artery disease; patients having hypothyroidism, significant gastrointestinal disease, renal and hepatic impairment, proliferative retinopathy and neuropathy requiring concurrent insulin use; pregnancy; females on oral contraceptives or hormone replacement therapy.

The study was approved by the Institutional ethics committee of government medical college, Amritsar, Punjab, India and was conducted as per ICH-GCP guidelines. Before enrolling, informed consent was taken 
from all the patients and they were advised regarding diet control and physical activity.

The patients were randomly divided into one of three subgroups i.e. group A, group B and group C comprising of 20 patients each. Group A received glipizide $5 \mathrm{mg}$ once daily 30 minutes before breakfast, group B received fenugreek seed extract $500 \mathrm{mg}$ twice a day half an hour prior to breakfast and dinner, group $\mathrm{C}$ received glipizide $2.5 \mathrm{mg}$ once daily before breakfast and fenugreek seed extract $500 \mathrm{mg}$ once daily 30 minutes prior to dinner. The fenugreek seed extract used was a hydroalcoholic extract of fenugreek seeds available commercially in the form of capsules of $500 \mathrm{mg}$ each.

\section{Laboratory procedures}

After taking initial base line at 0 week, fasting blood glucose (FBG) levels were repeated at intervals of 2, 4, 8 and 12 weeks. HbA1c levels and lipid profile (TC, LDLC, HDL-C, and TG) were estimated at 0 week and 12 week of the study period. The patient's hospital visit was scheduled so that the blood samples were drawn in the morning after 12 hours overnight fast. Fasting blood glucose was analysed using GOD/POD method. ${ }^{39}$ For HbA1c and lipid profile, blood was allowed to clot at room temperature and serum was analysed by centrifugation at $2000 \mathrm{rpm}$ for 10 minutes at $37{ }^{0} \mathrm{C}$. HbA1c level was determined by Ion Exchange Resin Method. $^{40,41}$
The TC and HDL-C levels were determined using CHOD/POD-phosphotungstate method, as described by Allain et al (Using liquichem cholesterol and HDL cholesterol KIT). ${ }^{42}$ The serum triglyceride estimation was determined by Bucolo and David method, 1973 (Using Triglyceride Kit-human, 20X $50 \mathrm{ml}){ }^{43}$ The LDL-C level was calculated using the formula by Friedewald et al (1972): LDL=TC-HDL-TG/5 (For TG<400 mg/dl). ${ }^{44}$ The instrument used for analysis of blood samples was spectrophotometer (spectronic 20) from Milton Roy, USA. These investigations were conducted in the department of pharmacology of Guru Nanak Dev Hospital, Amritsar, Punjab, India using enzymatic kit methods.

\section{Statistical analysis}

The data were tabulated as mean \pm standard deviation. Results were analysed using the Chi-square test, student t-test and ANOVA (one-way), using Graphpad Instat 3 software. A p-value <0.05 was considered statistically significant.

\section{RESULTS}

A total of 60 patients (29 male and 31 females) completed this study. No patient dropped out from the study. The mean age of the patients was $56.45 \pm 10.3$ years. The demographic and baseline laboratory characteristics of the patients were comparable between the treatment groups (Table 1).

Table 1: Baseline demographic and laboratory characteristics of patients in study groups.

\begin{tabular}{|c|c|c|c|}
\hline Baseline characteristics & Glipizide $n=20$ & Fenugreek $n=20$ & Glipizide+fenugreek $n=20$ \\
\hline Age (years) & $56.75 \pm 10.67$ & $52.95 \pm 11.23$ & $59.65 \pm 7.99$ \\
\hline Sex (M:F) & $10: 10$ & $10: 10$ & $9: 11$ \\
\hline Family H/o diabetes & $n=7(35 \%)$ & $n=4(20 \%)$ & $n=6(30 \%)$ \\
\hline Mean body weight (Kg) & $68.9 \pm 7.45$ & $71.45 \pm 11.87$ & $70.9 \pm 12.12$ \\
\hline $\mathrm{FBG}(\mathrm{mg} / \mathrm{dl})$ & $172.2 \pm 18.96$ & $164.9 \pm 18.72$ & $173.55 \pm 16.94$ \\
\hline HbA1c (\%) & $8.365 \pm 1.16$ & $7.932 \pm 0.9$ & $7.788 \pm 0.99$ \\
\hline $\mathrm{TC}(\mathrm{mg} / \mathrm{dl})$ & $197.45 \pm 31.92$ & $185.3 \pm 24.18$ & $181.85 \pm 21.65$ \\
\hline Triglycerides (mg/dl) & $199.96 \pm 31.71$ & $182.91 \pm 29.21$ & $181.65 \pm 32.58$ \\
\hline LDL-C (mg/dl) & $112.8 \pm 26.21$ & $105.41 \pm 20.23$ & $102.79 \pm 19.48$ \\
\hline HDL-C (mg/dl) & $43.7 \pm 5.59$ & $43.31 \pm 4.46$ & $42.74 \pm 4.20$ \\
\hline
\end{tabular}

All values expressed in mean \pm SD, except sex and family history of diabetes; SD, standard deviation.

\section{Fasting blood glucose}

A statistically significant decline in mean FBG levels was observed in group A by $33.97 \%(-58.5 \pm 9.5 \mathrm{mg} / \mathrm{dl}$, $\mathrm{p}<0.001)$; in group B by $24.62 \%(-40.6 \pm 7.27 \mathrm{mg} / \mathrm{dl}$, $\mathrm{p}<0.001)$; and in group $\mathrm{C}$ by $29.96 \%(-52 \pm 9.02 \mathrm{mg} / \mathrm{dl}$, $\mathrm{p}<0.001)$, after 12 weeks of treatment (Table 2 and Figure1).
Intergroup analysis of FBG levels showed statistically significant difference between the treatment groups $(\mathrm{p}=0.0443)$ and post-hoc test revealed statistically significant difference only between group $\mathrm{A}$ and $\mathrm{B}$ $(<0.05)$. Glipizide monotherapy was thus most efficacious in controlling FBG levels, followed by combination group, and then by fenugreek monotherapy. ADAs goal of $\mathrm{FBG} \leq 130 \mathrm{mg} / \mathrm{dl}$ was achieved in additional 17 (85\%), 13 
(65\%) and $16(80 \%)$ patients in group $\mathrm{A}, \mathrm{B}$ and $\mathrm{C}$, respectively, when compared to the baseline values (Table 3).

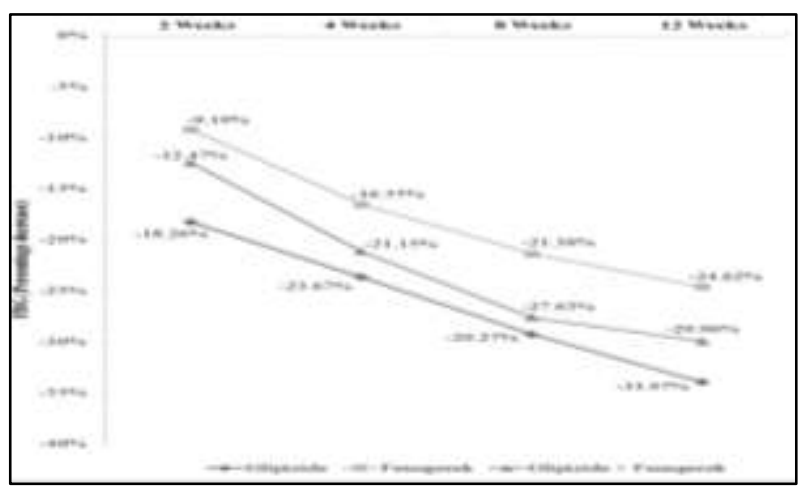

Figure 1: Percentage decrease in fasting blood glucose levels over the study period.

\section{Glycated haemoglobin}

Similarly, statistically significant decrease in HbA1c levels was seen in all three treatment groups. Group A showed reduction in $\mathrm{HbA} 1 \mathrm{c}$ by $12.98 \%(-1.086 \pm 0.41 \%$, $\mathrm{p}<0.0001)$, group $\mathrm{B}$ by $9.38 \%, \quad(-0.744 \pm 0.31 \%$, $\mathrm{p}<0.0001)$, and group $\mathrm{C}$ by $10.62 \% \quad(-0.827 \pm 0.34 \%$, $\mathrm{p}<0.0001)$ (Table 3).

However, intergroup analysis showed statistically nonsignificant $(\mathrm{p}=0.522)$ difference between the three treatment groups, although glipizide alone showed maximum decrease in mean HbA1c levels, followed by combination group and then by fenugreek monotherapy. The ADAs desired goals of HbA1c $<7.0 \%$ were achieved in $9(45 \%), 4(20 \%)$ and $6(30 \%)$ patients in group A, B and $\mathrm{C}$ respectively, over and above the baseline values (Table 3).

Table 2: FBG and HbA1c levels expressed in mean \pm SD at baseline and after 12 weeks.

\begin{tabular}{|c|c|c|c|c|c|c|c|c|c|}
\hline & \multicolumn{3}{|c|}{ Group A } & \multicolumn{3}{|c|}{ Group B } & \multicolumn{3}{|c|}{ Group C } \\
\hline $\mathrm{Ba}$ & line & $\begin{array}{l}\text { After } 12 \\
\text { weeks }\end{array}$ & $\begin{array}{l}\text { Mean } \\
\text { difference }\end{array}$ & Baseline & $\begin{array}{l}\text { After } \\
12 \\
\text { weeks }\end{array}$ & $\begin{array}{l}\text { Mean } \\
\text { difference }\end{array}$ & Baseline & $\begin{array}{l}\text { After } 12 \\
\text { weeks }\end{array}$ & $\begin{array}{l}\text { Mean } \\
\text { difference }\end{array}$ \\
\hline $\begin{array}{l}\text { FBG } \\
(\mathrm{mg} / \mathrm{dl})\end{array}$ & $\begin{array}{l}172 . \pm \\
18.96\end{array}$ & $\begin{array}{l}113.7 \pm \\
12.99\end{array}$ & $\begin{array}{l}58.5 \pm \\
7.47 *\end{array}$ & $\begin{array}{l}164.9 \pm \\
18.72\end{array}$ & $\begin{array}{l}124.3 \pm \\
14.93\end{array}$ & $\begin{array}{l}40.6 \pm 7.2 \\
7 *\end{array}$ & $173.55 \pm 16.94$ & $\begin{array}{l}121.55 \pm 12 \\
63\end{array}$ & $52 \pm 9.01 *$ \\
\hline $\begin{array}{l}\text { HbA1c } \\
(\%)\end{array}$ & $\begin{array}{l}8.365 \\
\pm 1.16\end{array}$ & $\begin{array}{l}7.28 \pm \\
1.06\end{array}$ & $\begin{array}{l}1.086 \pm \\
0.33 *\end{array}$ & $\begin{array}{l}7.932 \pm \\
0.9\end{array}$ & $\begin{array}{l}7.188 \pm \\
0.80\end{array}$ & $\begin{array}{l}0.74 \pm \\
0.31 *\end{array}$ & $7.788 \pm 0.99$ & $6.961 \pm 0.84$ & $\begin{array}{l}0.83 \pm 0.34 \\
*\end{array}$ \\
\hline
\end{tabular}

$* \mathrm{p}<0.001$

Table 3: Range of FBG and HbA1c levels at baseline, and goals achieved after 12 weeks, as per ADA guidelines.

\begin{tabular}{|c|c|c|c|c|c|c|c|c|}
\hline & \multicolumn{4}{|c|}{ FBG } & \multicolumn{4}{|c|}{ HbA1c } \\
\hline & \multicolumn{2}{|c|}{$90-130 \mathrm{mg} / \mathrm{dl}$} & \multicolumn{2}{|c|}{$\geq 131 \mathrm{mg} / \mathrm{dl}$} & \multicolumn{2}{|c|}{$\leq 6.9 \%$} & \multicolumn{2}{|c|}{$\geq 7.0 \%$} \\
\hline & Baseline & $\begin{array}{l}\text { After } 12 \\
\text { week }\end{array}$ & Baseline & $\begin{array}{l}\text { After } 12 \\
\text { week }\end{array}$ & Baseline & $\begin{array}{l}\text { After } 12 \\
\text { week }\end{array}$ & Baseline & $\begin{array}{l}\text { After } 12 \\
\text { week }\end{array}$ \\
\hline Group A (n) & 1 & 18 & 19 & 2 & 2 & 11 & 18 & 9 \\
\hline Group B (n) & 0 & 13 & 20 & 7 & 2 & 6 & 18 & 14 \\
\hline Group C (n) & 0 & 16 & 20 & 4 & 4 & 10 & 16 & 10 \\
\hline
\end{tabular}

\section{Total cholesterol}

On completion of 12 weeks study period, group A showed non-significant reductions in TC by $0.98 \%(p=0.1982)$ (Table 4). However, group $\mathrm{B}$ and group $\mathrm{C}$ showed statistically significant decrease in TC by $5.66 \%$ $(\mathrm{p}<0.001)$ and $3.87 \%(\mathrm{p}<0.001)$, respectively. Intergroup analysis showed significant difference in TC levels between group $\mathrm{A}$ and $\mathrm{B}$, and group $\mathrm{A}$ and $\mathrm{C}$ at 12 weeks $(\mathrm{p}<0.05)$. The difference between group $B$ and group $C$ was non-significant, although fenugreek alone decreased TC levels slightly more than the combination group. As per ICMR guidelines, the desired goals of TC $<180 \mathrm{mg} / \mathrm{dl}$ was achieved in additional $-1(-5 \%), 3(15 \%)$ and $1(5 \%)$ patients in group $\mathrm{A}, \mathrm{B}$ and $\mathrm{C}$, respectively (Table 5).

\section{Triglycerides}

Statistically non-significant reduction in TG was seen in group A $(-0.74 \%, \mathrm{p}=0.0669)$, whereas group B $(-17.23 \%$, $\mathrm{p}<0.001)$ and group C $(-11.34 \%, \mathrm{p}<0.001)$ showed significant decrease in TG levels (Table 4). Intergroup analysis of TG levels showed significant difference between group A versus group B, and group A versus group $\mathrm{C}$ at 12 weeks $(\mathrm{p}<0.001)$; and the difference between group $\mathrm{B}$ and group $\mathrm{C}$ was non-significant 
(p>0.05), with fenugreek monotherapy showing greater fall in TG levels than the combination group. As per ADA guidelines, the desired goal of $\mathrm{TGs}<150 \mathrm{mg} / \mathrm{dl}$ was achieved in additional $0(0 \%), 8(40 \%)$ and $6(30 \%)$ patients in group $\mathrm{A}, \mathrm{B}$ and $\mathrm{C}$, respectively, in comparison to the baseline values as shown in (Table 5).

\section{Low density lipoproteins cholesterol}

LDL-C levels decreased non-significantly in group A ( $-0.74 \%, \mathrm{p}=0.5482)$, and showed statistically significant decrease in group B $(-4.15 \%, \mathrm{p}<0.001)$, and group C (-2.68\%, $\mathrm{p}=0.0463)$ (Table 4). Non-significant difference was observed on intergroup analysis of LDL-C between group A, B, \& C at 12 weeks ( $>>0.05)$, although fenugreek group showed maximum decrease in LDL-C levels, followed by the combination group and then by glipizide group. The ADA guidelines target of LDL-C< $100 \mathrm{mg} / \mathrm{dl}$ were achieved in $0(0 \%), 1(5 \%)$ and $-1(-5 \%)$ patients in group $\mathrm{A}, \mathrm{B}$ and $\mathrm{C}$, respectively over and above the corresponding baseline values (Table 5).

Table 4: Lipid levels (mg/dl) expressed in mean \pm SD at baseline and after 12 weeks.

\begin{tabular}{|c|c|c|c|c|c|c|c|c|c|}
\hline \multirow[b]{2}{*}{ Parameters } & \multicolumn{3}{|l|}{ Group A } & \multicolumn{3}{|l|}{ Group B } & \multicolumn{3}{|l|}{ Group C } \\
\hline & Baseline & $\begin{array}{l}\text { After } 12 \\
\text { weeks }\end{array}$ & p-value & Baseline & $\begin{array}{l}\text { After } 12 \\
\text { weeks }\end{array}$ & $\mathrm{p}$-value & Baseline & $\begin{array}{l}\text { After } 12 \\
\text { weeks }\end{array}$ & $\mathrm{p}$-value \\
\hline $\begin{array}{l}\text { Total } \\
\text { cholesterol }\end{array}$ & $\begin{array}{l}197.45 \pm \\
31.92\end{array}$ & $\begin{array}{l}195.5 \pm \\
32.29\end{array}$ & 0.1982 & $\begin{array}{l}185.3 \pm 2 \\
4.18\end{array}$ & $\begin{array}{l}174.8 \pm \\
22.38\end{array}$ & $<0.0001$ & $\begin{array}{l}181.85 \pm \\
21.65\end{array}$ & $\begin{array}{l}174.8 \pm \\
22.44\end{array}$ & $<0.0001$ \\
\hline Triglyceride & $\begin{array}{l}199.96 \pm \\
31.71\end{array}$ & $\begin{array}{l}198.47 \pm \\
33.36\end{array}$ & 0.0669 & $\begin{array}{l}182.91 \pm \\
29.21\end{array}$ & $\begin{array}{l}151.4 \pm \\
22.24\end{array}$ & $<0.0001$ & $\begin{array}{l}181.65 \pm \\
32.58\end{array}$ & $\begin{array}{l}159.2 \pm \\
25.89\end{array}$ & $<0.0001$ \\
\hline $\begin{array}{l}\text { LDL } \\
\text { cholesterol }\end{array}$ & $\begin{array}{l}112.8 \pm \\
26.21\end{array}$ & $\begin{array}{l}111.97 \pm \\
28.49\end{array}$ & 0.1529 & $\begin{array}{l}105.41 \pm \\
20.23\end{array}$ & $\begin{array}{l}101.03 \pm \\
19.63\end{array}$ & 0.2072 & $\begin{array}{l}102.79 \pm \\
19.48\end{array}$ & $\begin{array}{l}100.03 \pm \\
20.18\end{array}$ & 0.0543 \\
\hline $\begin{array}{l}\text { HDL } \\
\text { cholesterol }\end{array}$ & $\begin{array}{l}43.7 \pm \\
5.59\end{array}$ & $\begin{array}{l}43.44 \pm \\
5.24\end{array}$ & 0.5482 & $\begin{array}{l}43.31 \pm \\
4.46\end{array}$ & $\begin{array}{l}43.59 \pm \\
4.5\end{array}$ & $<0.0001$ & $\begin{array}{l}42.74 \pm \\
4.2\end{array}$ & $\begin{array}{l}43.06 \pm \\
3.92\end{array}$ & 0.0463 \\
\hline
\end{tabular}

Table 5: Range of lipid levels at baseline and goals achieved after 12 weeks, as per ADA guidelines.

\begin{tabular}{|c|c|c|c|c|c|c|c|c|}
\hline \multirow{2}{*}{ Lipid levels } & \multicolumn{2}{|c|}{$\mathrm{TC}<180(\mathrm{mg} / \mathrm{dl})^{\wedge}$} & \multicolumn{2}{|c|}{ LDL $<100$ (mg/dl) } & \multicolumn{2}{|c|}{ TG<150 (mg/dl) } & \multicolumn{2}{|c|}{ HDL > 45 (mg/dl) } \\
\hline & Baseline & $\begin{array}{l}\text { After } 12 \\
\text { week }\end{array}$ & Baseline & $\begin{array}{l}\text { After } 12 \\
\text { week }\end{array}$ & Baseline & $\begin{array}{l}\text { After } 12 \\
\text { week }\end{array}$ & Baseline & $\begin{array}{l}\text { After } 12 \\
\text { week }\end{array}$ \\
\hline Group A (n) & 7 & 6 & 8 & 8 & 0 & 0 & 6 & 6 \\
\hline Group B (n) & 10 & 13 & 8 & 9 & 3 & 11 & 6 & 6 \\
\hline Group C (n) & 9 & 10 & 10 & 9 & 3 & 9 & 3 & 4 \\
\hline
\end{tabular}

${ }^{\wedge}$ The goals were as per ADA guidelines, except for total cholesterol where ICMR guidelines were followed.

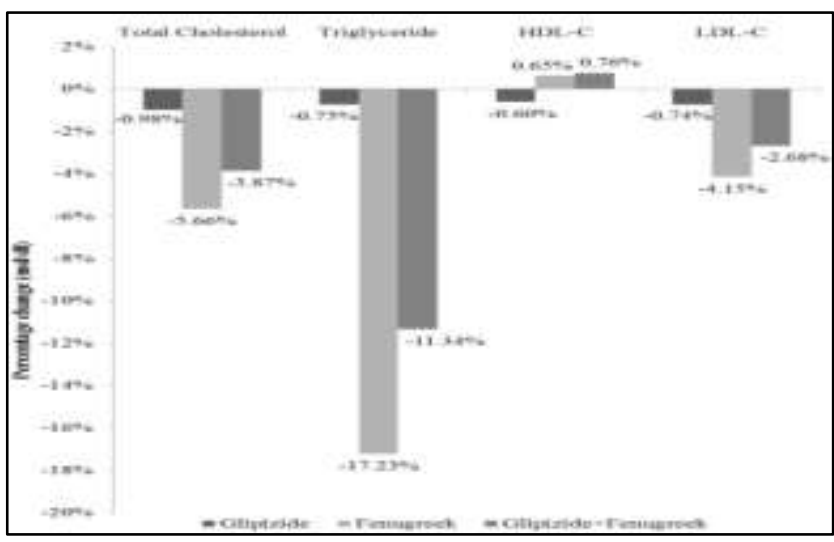

Figure 2: Percentage change in lipid levels over the study period.

\section{High density lipoproteins cholesterol}

Changes in HDL-C levels were statistically nonsignificant in all three groups at 12 weeks: group A showed a reduction in its levels by $0.60 \%(p=0.1529)$ whereas group $\mathrm{B}$ and $\mathrm{C}$ showed an increase in HDL-C values by $0.65 \% \quad(p=0.2072)$ and $0.76 \% \quad(p=0.0543)$ respectively (Table 4 and Figure 2). Intergroup analysis showed non-significant difference in HDL-C levels between group $\mathrm{A}, \mathrm{B}$, and $\mathrm{C}$ at 12 weeks $(\mathrm{p}>0.05)$; although the combination group of fenugreek and glipizide was slightly better in controlling HDL-C levels than fenugreek group. As per ADA guidelines, the desired goal of HDL-C $>45 \mathrm{mg} / \mathrm{dl}$ was achieved in additional 0 $(0 \%), 0(0 \%)$ and $1(5 \%)$ patients in group A, B and C, respectively (Table 5). 
Table 6: Number and type of adverse drug reactions in the three treatment groups.

\begin{tabular}{|c|c|c|c|}
\hline $\begin{array}{l}\text { Adverse drug } \\
\text { reactions }\end{array}$ & $\begin{array}{l}\text { Group } \\
\text { A }\end{array}$ & $\begin{array}{l}\text { Group } \\
\text { B }\end{array}$ & $\begin{array}{l}\text { Group } \\
\text { C }\end{array}$ \\
\hline \multicolumn{4}{|c|}{ Gastrointestinal tract } \\
\hline Dyspepsia & - & 2 & - \\
\hline Pain abdomen & - & 1 & - \\
\hline $\begin{array}{l}\text { Flatulence/abdominal } \\
\text { bloating }\end{array}$ & - & 5 & 2 \\
\hline Diarrhoea & - & 1 & - \\
\hline Nausea & 1 & - & - \\
\hline \multicolumn{4}{|l|}{ Other } \\
\hline Hypoglycemia & 1 & - & - \\
\hline Headache & 2 & - & - \\
\hline
\end{tabular}

\section{Adverse drug reactions}

$15(25 \%)$ adverse drug reactions (ADRs) were reported in 60 patients included in the study (Table 6). Maximum 9 $(15 \%)$ of the ADRs were seen in patients on fenugreek as gastrointestinal adverse effects of dyspepsia, pain abdomen, abdominal bloating and diarrhoea; one patient had both pain abdomen and abdominal bloating. All the ADRs were mild in nature and none of the patient was withdrawn from the study because of serious adverse drug reactions.

\section{DISCUSSION}

Our results indicate that fenugreek seed extract $500 \mathrm{mg}$ twice daily have hypoglycaemic and hypolipidaemic effects. As compared to the standard oral hypoglycaemic drug glipizide, which showed almost no effect on lipid profile, fenugreek caused significant improvement in dyslipidemia. Glipizide, on the other hand displayed better effect on glycaemic control than fenugreek. In combination therapy of fenugreek and glipizide, favourable effects were observed on both glycaemic control and lipid profile, which has shown addition of their pharmacological actions on said parameters.

\section{Glycaemic control}

In the present study, glipizide $5 \mathrm{mg}$ once daily caused significant improvement in glycaemic control, as shown by significant decrease in FBG and HbAlc levels after 12 weeks of treatment. The hypoglycaemic effect of glipizide is well documented. In a similar study, a reduction in FBG levels by $42 \mathrm{mg} / \mathrm{dl}(25 \%)$ and HbAlc levels of $1.8 \%$ with glipizide therapy was reported by Testa et $\mathrm{al}^{45}$ In another study, reduction in FBG level by $57-74 \mathrm{mg} / \mathrm{dl}$ and in $\mathrm{HbA} 1 \mathrm{c}$ levels of $1.5-1.82 \%$ after 3-5 month treatment with glipizide have been observed. ${ }^{46}$ Our study showed similar decrease in FBG levels, but lesser decrease in HbA1c levels.

Patients on fenugreek monotherapy also showed a statistically significant improvement in glycaemic control, although lesser than glipizide. In a similar double blind study by Gupta et al in 25 patients with T2DM on $500 \mathrm{mg}$ twice daily dose of fenugreek seed extract, a reduction in FBG levels by $19.15 \%$ ( $148.3 \pm 44$ to $119.9 \pm 25)$ and in HbAlc levels by $8.61 \%(8.25 \pm 1.2$ to $7.54 \pm 0.9)$ over a study period of 8 weeks was reported. ${ }^{22}$ Our study showed similar decrease in FBG levels by $21.38 \%$ at 8 weeks (Figure 1), and in HbAlc levels at 12 weeks. Another study involving 60 patients with type 2 diabetes whose diets were supplemented with $25 \mathrm{~g}$ powdered fenugreek seeds per day for 24 weeks, patients with mild type 2 diabetes were benefitted the most and were able to completely withdraw from the use of oral medications and insulin. ${ }^{47}$ Also, the hypoglycaemic effect of fenugreek has been shown by studies of Sharma et al, Bordia A et al, Sharma RD et al. ${ }^{23,24,48}$ These above studies except the one by Gupta et al, have used powdered fenugreek seeds, whereas in our study the hydro-alcoholic extract of fenugreek seeds was used; it could probably be associated with similar effects at lower dose.

The defatted seed that remains after lipid extraction is primarily thought to be responsible for lowering blood glucose levels. ${ }^{29,38}$ The hypoglycemic effects of fenugreek is attributed to several mechanisms: 4-hydroxyisoleucine, an amino acid extracted from fenugreek seeds increases glucose-induced insulin secretion from pancreatic beta cells; fibre in the seed delays gastric emptying and slows carbohydrate absorption; activates insulin signaling pathways in adipocytes and liver cells, leading to stimulatory effect on cellular glucose uptake; inhibits the activities of alpha-amylase and sucrase, two intestinal enzymes involved in carbohydrate metabolism; increases the number of insulin receptors, and improve peripheral glucose utilization; improves insulin sensitivity and decreases insulin resistance. ${ }^{22,49-52}$ Certain studies have shown that fenugreek has no effect on fasting or postprandial blood glucose in non-diabetic subjects. ${ }^{24}$

Combination therapy with fenugreek and glipizide also showed significant improvement in glycaemic control. There is no such study in literature that reports a combination of fenugreek and glipizide. Although half the doses of monotherapy of glipizide and fenugreek were used, glycaemic control was better than that of fenugreek alone.

\section{Lipid profile}

Studies have shown that glipizide does not show significant effect on lipid profile, and also was not shown in this study. The results of the present study are in consistent with diabetes control and complication trial research group and UK prospective diabetes study group. 53,54 
In the present study, administration of fenugreek seed extract $500 \mathrm{mg}$ twice daily caused a statistically significant improvement in dyslipidemia, except for HDL-C where it caused non-significant increase. Also, among the lipoproteins, LDL-C is considered to be one of the most important risk factor in causing CHD; however the reduction in LDL-C were much lesser than with TGs and slightly less than TC. Similar study by Gupta et al reported that incorporating 1 gram per day of hydroalcoholic extract of fenugreek seed in patients with T2DM over 8 weeks decreased the levels of TGs by $28.88 \%(-53.2 \mathrm{mg} / \mathrm{dl})$ from the initial baseline concentrations. However, the levels of TC, LDL-C and HDL-C increased by $8.1 \%$ (14 mg/dl), $19.74 \%$ (18.3 $\mathrm{mg} / \mathrm{dl})$ and $4.19 \%(1.9 \mathrm{mg} / \mathrm{dl})$, respectively. ${ }^{22}$ Our study showed significant but lesser decrease in TGs and much lesser increase in HDL-C, however TC and LDL-C levels decreased significantly; these could be associated with longer duration of the present study conducted over 12 weeks in comparison to 8 weeks by Gupta et al. In another study, which involved administration of defatted fenugreek seeds powder $(50 \mathrm{gm} / \mathrm{d}$ and $100 \mathrm{gm} / \mathrm{d}$ to different groups) over 20 days, showed that the levels of TC were decreased by $26.07 \%$ and $33.1 \%$, TGs by $26.5 \%$ and $39.26 \%$, and LDL-C by $30.6 \%$ and $38.22 \%$ in groups on $50 \mathrm{gm} / \mathrm{d}$ and $100 \mathrm{gm} / \mathrm{d}$ powder respectively. The levels of HDL-C were decreased by $6.67 \%$ and $6 \% .^{32}$ Another study shows the effect of fenugreek on 15 non obese, asymptomatic, hyperlipidemic adults administered $100 \mathrm{~g}$ defatted fenugreek powder per day for three weeks. Their TG and LDL-C levels were lower than baseline values and slight decreases in HDL levels were also noted. ${ }^{33}$ Lipid profiles were normalized in 60 patients with T2DM whose diets were supplemented with $25 \mathrm{~g}$ powdered fenugreek seeds per day for 24 weeks. ${ }^{30}$ Also, the anticholesterolemic actions of fenugreek has been shown by studies of Bordia et al, Sharma RD et al. ${ }^{23,24}$ These above studies show better effect on lipid profile than the present study, this probably could be associated with much larger doses of fenugreek seed powder administered over shorter duration in these studies. Also, all these studies except the one by Gupta et al have used fenugreek seed powder, whereas in our study the hydroalcoholic extract of fenugreek seeds was used, which could probably be associated with similar effects at lower dose.

A number of mechanisms are responsible for hypolipidaemic effects of fenugreek; inhibit the intestinal absorption of cholesterol, this is attributed to sapogenins which absorb bile acids and increase their excretion in faeces, which leads to an increased conversion of cholesterol into bile acids by the liver, thus decreasing its levels. ${ }^{36,55-57}$ Another mechanism is attributed to fibre in the seed, it absorbs bile salts and might influence the enterohepatic circulation of bile acids and enhances cholesterol metabolism, thus reducing triglyceride levels. ${ }^{58}$ Also, the estrogenic constituent of fenugreek may cause decrease in lipid levels, by indirectly increasing thyroid hormone $\mathrm{T} 4 .^{59}$
In patients on combination therapy, a statistically significant improvement in lipid profile is seen except that for HDL-C which showed non-significant increase. The improvement was however, lesser than that seen with fenugreek monotherapy. Literature search could not reveal any study involving a combination of fenugreek and glipizide.

\section{Safety profile}

Glipizide monotherapy was well-tolerated by the patients, and safety profile was similar to earlier studies. ${ }^{47,48}$ Earlier investigators had reported excellent tolerability profile with fenugreek seeds, and was similarly observed in the present study, although in our study more number of patients $(40 \%)$ on fenugreek monotherapy had ADRs, which were mild in nature and most improved after few days of use. ${ }^{22}$ It has also been observed that ADRs of fenugreek on gastrointestinal system are dose-dependent, as in the combination therapy, only $10 \%$ of patients experienced these adverse effects.

Some limitations associated with the study were small sample size; the patients were followed only over 12 weeks, longer follow-up would have revealed better effect on the efficacy and safety of the drugs; and the study was open-label.

\section{CONCLUSION}

In conclusion, Glipizide and fenugreek seed extract as monotherapy and combination therapy showed significant improvement in glycaemic control in patients with type 2 diabetes at the end of 12 weeks study period; with glipizide showing superior efficacy followed by combination group and then by fenugreek monotherapy. Glipizide monotherapy had no favourable effect on lipid profile; fenugreek as monotherapy and in combination with glipizide produced significant improvement in dyslipidaemia, with fenugreek monotherapy showing better response. The drugs were safe and well tolerated. Fenugreek seed extract as monotherapy or add-on therapy can prove to be a useful agent in treatment of mild type 2 diabetes mellitus with or without dyslipidaemia, provided its favourable effects are confirmed in multi-centric trials involving larger number of patients over longer duration.

\author{
Funding: No funding sources \\ Conflict of interest: None declared \\ Ethical approval: The study was approved by the \\ Institutional Ethics Committee
}

\section{REFERENCES}

1. Syvanne M, Taskinen MR. Lipids and lipoproteins as coronary risk factors in non-insulin-dependent diabetes mellitus. Lancet. 1997;350:120-3.

2. Haffner SM. Management of dyslipidemia in adults with diabetes. Diabetes Care. 1998;21:160-78. 
3. Betteridge DJ. Dyslipidemia and diabetes. Practical Diab Int. 2001;18:201-7.

4. Betteridge DJ. Treating dyslipidaemia in the patients with type 2 diabetes. Eur Heart J. 2004;6:28-33.

5. Pyorala K, Laasko M, Uusitupa M. Diabetes and atherosclerosis: an epidemiologic view. Diabetes Metab Rev. 1987;3(2):463-524.

6. Stamler J, Vaccaro O, Neaton JD, Wentworth D. Diabetes, its risk factors and 12 year cardiovascular mortality for men screened in multiple risk factor intervention trial. Diabetes Care. 1993;16:434-44.

7. Ho JE, Paultre F, Mosca L. Is diabetes mellitus-a cardiovascular disease risk equivalent for fatal stroke in women? Data from the women pooling project. Stroke. 2003;34:2812-16.

8. McCarran P, Greenwood R, Elwood P. The incidence and aetiology of stroke in Carephilly and Speedwell collaborative studies II: risk factors for ischaemic stroke. Public Health. 2001;115:12-20.

9. Chun BY, Dobson AJ, Heller RF. The impact of diabetes on survival among patients with first myocardial infarction. Diabetes Care. 1997;20:704-08.

10. Wannamethee G, Whincup PH, Shaper AG, Walker Monotherapy, MacFarlane PW. Factors determining case fatality in myocardial infarction, who dies in a heart attack? Br Heart J. 1995;74:324-31.

11. DeJong, van Raak L, Kessels F, Lodder J. Glycaemic control, stroke subtype and mortality a follow-up study in 998 patients with a first cerebral infarct. J Clin Epidemiol. 2003;56:262-68.

12. Ginsberg HN. Diabetic dyslipidemia. In: Lebovitz HE, Editor. Therapy for diabetes mellitus and related disorders. $4^{\text {th }}$ ed. Virginia: American Diabetes Association; 2004:293-309.

13. Haffner SM, Lehto S, Ronnemaa T. Mortality from coronary heart disease in subjects with type 2 diabetes and in non-diabetic subjects with and without prior myocardial infarction. $\mathrm{N}$ Eng $\mathrm{J}$ Med. 1998;339(4):229-34.

14. Adult treatment panel III. Executive summary of third report of the national cholesterol education program (NCEP) expert panel on detection, evaluation and treatment of high blood cholesterol in adults. JAMA. 2001;285:2486-97.

15. Pyorala K, Pedersen TR, Kjekshus J, Faegeman O, Olsson AG, Thorgeirsson G. The scandinavian simvastatin survival study (4S) group: Cholesterol lowering with simvastatin improves prognosis of diabetic patients with coronary heart disease: a subgroup analysis of the scandinavian simvastatin survival study (4S). Diabetes Care. 1997;20:614-20.

16. Goldberg RB, Mellies MJ, Sacks FM. Cardiovascular events and their reduction with pravastatin in diabetic and glucose-intolerant myocardial infarction survivors with average cholesterol levels: subgroup analyses in the cholesterol and recurrent events (CARE) trial. The Care Investigators. Circulation. 1998;98:2513-9.
17. The long-term intervention with pravastatin in ischaemic disease (lipid) study group. Prevention of cardiovascular events and death with pravastatin in patients with coronary heart disease and a broad range of initial cholesterol levels. $\mathrm{N}$ Engl J Med. 1998;339:1349-57.

18. Haffner SM, Alexander CM, Cook TJ. Reduced coronary events in simvastatin-treated patients with coronary heart disease and diabetes or impaired fasting glucose levels: subgroup analyses in the scandinavian simvastatin survival study. Arch Intern Med. 1999;159:2661-7.

19. Heart protection study collaborative group: $\mathrm{MRC} / \mathrm{BHF}$ heart protection study of cholesterollowering with simvastatin in 20,536 high-risk individuals: a randomized placebo-controlled trial. Lancet. 2002;360:7-22.

20. Tools of therapy. In: Burant CF, editor. Medical management of type 2 diabetes. $5^{\text {th }}$ ed. Virginia: American Diabetes Association; 2004:27-77.

21. Indian council of medical research: guidelines for management of type 2 diabetes. 2005. Available at http://icmr.nic.in/guidelines_diabetes/guide_diabetes. htm. Accessed 2 March 2016.

22. Gupta A, Gupta R, Lal B. Effects of Trigonella foenum-graecum (Fenugreek) seeds on glycaemic control and insulin resistance in type 2 diabetes mellitus: a double blind placebo controlled study. JAPI. 2001;49:1057-61.

23. Sharma RD. Effect of fenugreek seeds and leaves on blood glucose and serum insulin responses in human subjects. Nutr Res. 1986;6:1353-64.

24. Bordia A, Verma SK, Srivastava KC. Effect of ginger (Zingiber officinale Rosc.) and fenugreek (Trigonella foenum graecum $L$ ) on blood lipids, blood sugar, and platelet aggregation in patients with coronary artery disease. Prostaglandins Leukot Essent Fatty Acids. 1997;56(5):379-84.

25. Madar Z, Abel R, Samish S. Glucose lowering effect of fenugreek in non-insulin dependent diabetics. Eur J Clin Nutr. 1988;42:51-4.

26. Al Hobori M, Raman. Antidiabetic and hypochoesterolaemic effects of fenugreek. Phytother Res. 1998;12:233-42.

27. Shani J, Goldschmied A, Joseph B, Ahronson Z, Sulman FG. Hypoglycaemic effects of Trigonella foenum-graecum and Lupinus Termis (Leguminosae) Seeds and their major alkaloids in alloxan-diabetic and normal rats. Arch int Pharmacodyn. 1974;201:27-37.

28. Khosla, Gupta DD, Nagpal RK. Effect of Trigonella foenum-graecum (Fenugreek) on blood glucose in normal and diabetic rats. Indian J Physiol Pharmacol. 1995;39(2):173-4.

29. Ribes G, Sauvaire Y, Baccou, JC. Effects of fenugreek seeds on endocrine pancreatic secretions in dogs. Ann Nutr Metab.1984;28:37-43.

30. Sharma RD, Sarkar A, Hazra DK. Hypolipidaemic effect of fenugreek seeds: A chronic study in non- 
insulin dependent diabetic patients. Phytother Res 1996;10:332-4.

31. Jain V, Jain P, Sharma SW, Kakani R. Hypolipidaemic activity of syndrex, a hydroalcoholic extract of fenugreek seeds: Single blind clinical study. Int med j. 1995;89:1-4.

32. Prasanna M. Hypolipidemic effect of fenugreek: a clinical study. Indian J Pharmac. 2000;32:34-6.

33. Sharma RD, Raghuram TC, Rao VD. Hypolipidaemic effect of fenugreek seeds. A clinical study. Phytother Res. 1991;3:145-7.

34. Sowmya P, Rajyalakshmi P. Hypocholesterolemic effect of germinated fenugreek seeds in human subjects. Plant Foods Hum Nutr. 1999;53(4):3599-65.

35. Valette G, Sauvaire Y, Baccou JC, Ribes G. Hypocholesterolaemic effect of fenugreek seeds in Dogs. Atherosclerosis. 1984;50:105-11.

36. Sauvaire Y, Ribes G, Baccou JC, Mariani MML. Implication of steroid saponins and sapogenisins in the hypocholesterolaemic effect of fenugreek. Lipids. 1991;26:191-7.

37. Jefferson C. Fenugreek in diabetes management. UM school of pharmacy and allied health sciences drug information centre. 1999;3(7):1-2.

38. Ribes G, Sauvaire Y, Costa DC, Baccou JC, Mariani MML. Antidiabetic effects of subfractions from fenugreek seeds in diabetic dogs. Proc Soc Exp Biol Med. 1986;182:159-66.

39. Trinder P. Ann clin Biochem. 1969;6:24.

40. Trivelli LA, Ranney HM, Lai HT. Haemoglobin components in patients with diabetes mellitus. N Eng J med. 1971;284(7):353-7.

41. Bunn HF. Evaluation of glycosylated haemoglobin diabetic patients. Diabetes. 1981;30(7):613-7.

42. Allain CC, Poon LS, Chan CSG, Richmond W. Enzymatic determination of total serum cholesterol. Clin Chemistry. 1974;29:470-4.

43. Bucolo G, David H. Quantitative estimation of serum triglycerides by use of enzymes. Clin Chemistry. 1973;19:476-8.

44. Friedewald WT, Levy RI, Fredrickson DS. Estimation of the concentration of low-density lipoprotein cholesterol in plasma, without use of the preparative ultracentrifuge. Clin Chemistry. 1972;18:499-5.

45. Testa MA, Simonson DC. Health economic benefits and quality of life during improved glycemic control in patients with type 2 diabetes mellitus. A randomized controlled, double blind trial. J Am Med Assoc. 1998;280:1490-6.

46. Simonson DC, Korides IA, Feinglos M, Shamoon H, Fischette CT. Efficacy, safety and dose response characteristics of glipizide gastrointestinal therapeutic system on glycemic control and insulin secretion in NIDDM; results of two multi-center randomized placebo-controlled chemical trials- The glipizide gastrointestinal therapeutic study group. Diabetes Care. 1997;20(4):597-606.

47. Sharma RD, Sarkar A, Hazra DK. Use of fenugreek seed powder in the management of non-insulin dependent diabetes mellitus. Nutr Res. 1996;16:1331-9.

48. Sharma RD, Raghuram TC. Hypoglycaemic effect of fenugreek seeds in non-insulin dependent diabetic subjects. Nutr Res. 1990;10:731-9.

49. Sauvaire Y, Petit P, Broca C, Manteghetti M, Baissac Y, Fernandez-Alvarez J, et al. 4-Hydroxyisoleucine: a novel amino acid potentiator of insulin secretion. Diabetes. 1998;47:206-10.

50. Vijayakumar MV, Singh S, Chhipa RR, Bhat MK. The hypoglycaemic activity of fenugreek seed extract is mediated through the stimulation of an insulin signalling pathway. British Journal of Pharmacology. 2005;146:41-8.

51. Amin R, Abdul-Ghani AS, Suleiman MS. Effect of Trigonella feonum graecum on intestinal absorption. Proc. of the $47^{\text {th }}$ annual meeting of the American Diabetes Association (Indianapolis U.S.A.). Diabetes. 1987;36:211.

52. Raghuram TC, Sharma RD, Sivakumar B, Sahay BK. Effect of fenugreek seeds on intravenous glucose disposition in non-insulin dependent diabetic patients. Phytother Res. 1994;8:83-6.

53. Diabetes control and complication trial research group. The effect of intensive treatment of diabetes on development and progression of long term complications in IDDM. $\mathrm{N}$ Engl $\mathrm{J}$ Med. 1993;329:977-86.

54. UK prospective diabetes study group: intensive blood-glucose control with sulphonylureas or insulin compared with conventional treatment and risk of complications in patients with type 2 diabetes (UKPDS 33). Lancet. 1998;352:837-53.

55. Stark A, Madar Z. The effect of an ethanol extract derived from fenugreek (Trigonella foenumgraecum) on bile acid absorption and cholesterol levels in rats. Br J Nutr. 1993;69:277-87.

56. Varshney IP, Sharma SC. Saponins and sapogenins: part XXXII. Studies on Trigonella foenum-graecum Linn seeds. J Indian Chem Soc. 1966;43:564-7.

57. Sidhu GS, Oakenfull DG. A mechanism for the hypocholesterolaemic activity of saponins. Br J Nutr. 1986;55:643-9.

58. Mohan V, Balasubramanyam M. Fenugreek and insulin resistance. JAPI. 2001;49:1055-6.

59. Basch E, Ulbricht C, Kuo G, Szapary P, Smith M. Therapeutic applications of fenugreek. Altern Medi Rev. 2003;8(1):20-7.

Cite this article as: Singh A, Rai J, Mahajan DS. Comparative evaluation of glipizide and fenugreek (Trigonella foenum-graecum) seeds as monotherapy and combination therapy on glycaemic control and lipid profile in patients with type 2 diabetes mellitus. Int J Basic Clin Pharmacol 2016;5:942-50. 